\title{
My Life with Charles Billups \& Martin Luther King: Trauma and the Civil Rights Movement
}

\section{Rene Billups Baker}

Peacock Proud Press, 2019, pp. 150

\section{Reviewed by Sherita Roundtree}

Towson University

$\mathrm{R}$ ene Billups Baker's book offers a personal and historical account of often overlooked details in the narratives of the civil rights movement: the legacies of fear and trauma faced by family members of civil rights leaders (4). The daughter of civil rights leader Charles Billups, Baker walks her reader through the untold stories of the civil rights movement in Birmingham, Alabama and her and her father's relationship with Dr. Martin Luther King Jr. as a close family friend. The genesis of My Life with Charles Billups and Martin Luther King derives from the disequilibrium Baker noticed between how the civil rights movement in Birmingham accounted for key figures in its success and what she knew to be true from her lived experience. She explains that Andrew Young's televised acknowledgement of her father's contributions to the civil rights movement tapped her on the shoulder and moved her to do the same, but that move to share came with its own set of obstacles. With the support of Keith Miller as well as Andrew Miller and Winston Baker (her husband), Baker began to share her story. She posits that "for years and years, [she] wasn't ready to do that because the whole experience was so painful," but she eventually started sharing her experience because "no books talk about Charles Billups' family" (1). Baker's family's and community's journey to healing and forgiveness serve as guiding principles for the events discussed in each chapter of My Life with Charles Billups and Martin Luther King.

Baker's book moves beyond some of the overlapping themes and tensions that members of the field might deem as inherit to civil rights scholarship to account for the narratives that have not been shared. She urges readers to disregard notions of literacy as historically tethered to aspects of reading and writing only and to see literacy as embodied and performed through protesting, demonstrating, and surviving. Baker explores how communities refigure local oppression-mediated by geographical scope-as a type of reclamation. Additionally, Baker challenges her reader to reconfigure timelines that mark Birmingham, Alabama as a catalyst for nonviolent, political unrest. She uses her own memories and conversations with family and friends 
to remap the narratives of the civil rights experience in 1950s and 1960s Birmingham, and includes newspaper clippings (alongside accessible reprints) and images as both evidence and affirmation of the stories being more than her own.

Chapter one introduces Charles Billups-civil rights leader, veteran, husband, friend, and father. Born in Jefferson County, Alabama in 1927, Baker explains that her father did not have a picturesque upbringing, but he was a devoted to being the change he wanted to see. However, Baker notes the dissonance between the recognition Billups received for his sacrifices to serve in the U.S. military and the fear, racism, and violence he faced when he returned home. For example, Billups became a minister of his own church, which the Ku Klux Klan burned down and, out of fear, the community never rebuilt. This led Billups to join as an associate minister of New Pilgrim Baptist Church of Birmingham. As Baker continues, she not only discusses Billups's belief in the power of African Americans being registered to vote as a countermeasure toward racism, she also describes how she wrestled with her embodiment of and fight for her father. Baker acknowledges, "sometimes I would be my daddy's mouthpiece" (9). Her book maps her journey in reconciling what it meant to serve as "daddy's mouth piece" at various stages of her life (Baker 9).

Chapter two, "We Must March to Complete Freedom" proposes a new timeline for the civil rights movement in Birmingham as starting in 1956 instead of 1963, which has traditionally been designated as the year of origin due the children's march. According to Baker, June 6, 1956 marks the "first official meeting" of the Alabama Christian Movement for Human Rights (ACMHR), a coalition of local church leaders and community members advocating for civil rights (11). Baker names key leaders in the movement as her father (Charles Billups), Reverend N.H. Smith, Reverend Ed Gardner, Reverend Fred Shuttlesworth, Lucinda Robey, Georgia Price, and Lola Hendricks. Here, Baker offers insight into some of the experiences of women in the movement both through their contributions and their traumas. She goes on to emphasize the excitement that energized the members and their organizing work, but that excitement was often counterbalanced by acts of violence enacted against the African American community in Birmingham. Reframing the narratives, nicknames often became a way of naming the violence that happened while turning it on its head as an act of survival. For example, nicknames like "Bombingham" and "Dynamite Hill" highlighted not only the frequency with which leaders such as Reverend Shuttlesworth faced bombing at home but also how fear of bombings created distrust among neighbors, through which civil rights advocates became a symbol of the threat to peace (Baker 14).

"Escaping a Lynching," the third chapter discusses the legacies of race-based trauma and the impact it had on Billups and his family's outlook on forgiveness. Baker explains that there were many close calls through which her proximity to her father put her life at risk (17). Due to the lack of media coverage in Birmingham from 1956-1960, Baker admits that it was difficult to track the progress and success of the civil rights work happening in the community. It required the ACMHR to lean on the community's hope and faith, but not necessarily their understanding. Despite the countless bombings and violent attacks against African American in all contexts, Baker noticed that no one was being held accountable for the fear that was being instilled in her or the backlash her family faced because of their African American neighbors' fear of the 
potential for retaliation. However, the police arrested Billups several times. Baker describes how helpless she felt when she had to bear witness to her father being arrested from their family home. She states, "I couldn't help him against the police. But he also knew I would try to help him" (Baker 18). It was through knowing-the oppressive environment they were fighting against, the goals and personalities of one another, and the risk at hand-that Baker and her father protected one another. Unfortunately, even in the moments of helplessness, like the night the Ku Klux Klan kidnapped and left scars of the harm done all over his body, Billups demonstrated a tool of resistance and healing that he always had at hand was forgiveness. Through prayer and forgiveness, Billups not only saved his life, but he planted the seed for what Baker's path to healing would require later down the road.

Social justice work takes a toll on each member of a family, not just those who actively participate or are in leadership positions; it uncovers the cost of justice. In chapters four and five, Baker explains how she and her mother battled with feelings of hate toward white people and the strain the civil rights movement put on her family's emotions and finances. However, Baker showcases how, in many ways, fear and tears had to be put on hold in order to not be left behind (36). In the case of Baker, Dr. King recognized early on that her path toward forgiveness would vary from that of her father's, to which Dr. King stated: 'I would hate to see her grow up with hate in her heart' (35). Nicknames also make another appearance in the form of both adults and children taunting Baker and her family with the label of "Jailbird," a criminalization of their fight for justice. As Baker notes, "They truly didn't understand what the civil rights movement was and why it was so important" (38). Chapter five continues on the conversation about how the often unforeseeable and intangible state of social justice can make quitting the fight appear as the best option. But as Baker emphasizes, quitting was never an option for Billups.

Chapter six accounts for the role of children in the Birmingham civil rights movement that countered the lack of adult participation due to fears of retaliation. With a significant increase of children participating in the demonstrations, a two-day demonstration in 1963 led to overpacked prisons and alternative actions for holding demonstrators under arrest. "Creating a Miracle," the seventh chapter of the book, builds on the demonstrations discussed in chapter six and documents one of the peak moments in Birmingham's nonviolent civil rights history. The chapter provides a detailed account of the 1963 Birmingham Children's March and the refusal of firefighters to use the firehoses as a weapon against the demonstrators, primarily because of the overwhelming presence of children (Baker 58). As Baker notes, "When the firefighters dropped their hoses, that decision strengthen people's resolve and their faith in nonviolence" (59). Baker highlights a type of awakening among African American adults in Birmingham to see that the movement was not an affront to their peace. Instead, the movement used peace as an actionable tool toward civil liberties. Baker emphasizes fear had little space for demonstrators at the march, but song acted as a balm for that fear. Quoting Myrna Carter, one of the women who attend the march, Baker reports, "We were afraid of the dogs, but we were not to show fear. We were to keep walking and singing as if they were not there"' (55). The march gained national attention and forced the city to take measures to salvage its reputation in the face 
of the country, which led to negotiations and the organizers requests being honored. Although the agreement ended demonstrations on Birmingham, it served as the catalyst for demonstrations across the country and compelled President John Kennedy to draft a civil rights bill that President Lyndon B. Johnson got passed into law-the Civil Rights Act of 1964.

As civil rights progress became more visible in Birmingham, Baker shares how attacks against those civil rights also increased. The second bombing of NAACP lawyer Arthur Shores' family home and the bombing of the Sixteenth Street Baptist Church, which killed Addie Mae Collins, Denise McNair, Carole Robertson, and Cynthia Wesley set the precedent that African Americans in Birmingham were not free from violence in any space or at any time, including home and church. Baker recalls how her and her father were only minutes away from being at Sixteenth Street Baptist Church because they received an invitation to attend Youth Day. Even in its tragedy, these two bombings foreshadow the critical role the children played in civil rights actions in Birmingham and the vulnerabilities they had to confront. Baker expresses, "I cried because I wanted to see it myself and to learn what was happening. I wanted to help, too. Even though I was only nine or ten years old, I thought I could do anything" (73). As a young person, Baker describes feeling invincible while also having to come to terms with the reality of her constraints and vulnerability.

In chapters nine and ten, "Trading Birmingham for Chicago" and "The Worst Day," Baker calls attention to the brevity of human life and the murder of her father, alongside prolonged grief and healing. In 1966 Dr. King moved to Chicago and asked Billups to join him. Baker describes her excitement about the next chapter in her life in a new city, distanced from the one that had caused her such harm. This excitement somewhat mirrored the energy of the early days of ACMHR, but it was a new start. However, Baker reveals how her father and family's documented reputation as trouble makers-due to arrests from protests and activism-followed them to the upper Midwest and made seeking employment difficult. With time, Billups landed a supportive job and it served as a site of one of Baker's literacy experiences-learning to type and acting as her father's secretary. But with joy also came the reality of danger, the type of fear and danger through which Baker understood her growing desire to protect her father. Only a couple years after moving to Chicago at the request of Dr. King, Baker learned of Dr. King's murder in April 1968 and her father's murder in October 1968. Billups murder remains unsolved and the motive uncertain. She recalls the fear that she had in Birmingham but now it accompanied numbness and, again, she and her family feared for their safety. Baker states "Over and over my mother kept telling me that I could never talk about my father's murderer to anyone. So I didn't" (86). She became silenced by the reality of what she knew and by the fear of what she did not.

Chapters eleven, twelve, and thirteen document the puzzle pieces in Baker's life journey that allowed her to begin healing, understand her complex feelings about her father and his roles in the civil rights movement, and explore the narrative contributions that she would soon take on. Chapter eleven narrates the hurt and abandonment Baker felt after her father's murder. As Baker notes, "Back then, I wouldn't talk to people about my background and my life. When someone would ask, I would 
say, "Get out of my face!" For fifteen years, I hated God for taking my daddy away, so I refused to talk to God" (Baker 91). However, after meeting her husband Winston during a visit to see her sister, Baker opened up a bit more to what life had in store for her. Winston was able to see Baker as "a nice person" but "also realized that [she] didn't like white people" due to the trauma she and her family had experienced because of racism (92). Like her father, Winston was in the military, and so Baker got to travel and live in various part of the world that challenged what she considered the norm but there were also triggering familiarities. Chapter twelve revisits Baker's identity as "little Billups" and her path to understanding what forgiveness would look like within her life, which did not necessarily model her father's approaches to forgiveness. Therefore, birds, as described in chapter thirteen "A Tale of Two Parakeets" serve as a metaphor for Baker and demonstrate that recovering and healing take time.

In the final chapter, Baker describes reckoning with the belief that "God left [her] here for a reason" and her experiences growing up at the height of the civil rights movement (105). The disappointment and anger Baker felt after learning that Barnett Wright, a local news reporter, used an image of Billups and Dr. King for the cover of his book while omitting Billups from the book itself, propelled Baker to break her silence. The narratives that had been made accessible were failing to acknowledge the pivotal role that Billups played in racial protests of the 1950s and 1960s in Birmingham, and Baker identifies this moment as a shift in her outlook. Even in his passing, Baker found herself still fighting for her father again. Baker acknowledges the ways that traumatic experiences can silence voices, but they can also create bonds shared beyond conversations with her husband to a public audience. She also goes on to discuss the role of the media in the civil rights movement and how it acted as a signal of protest progress to non-local observers. Shared knowledge acted as the means for keeping the common goal at the forefront of demonstrators' minds-even though Birmingham was often overlooked for the multifaceted role it played in developing national buy-in regarding nonviolence as a tool of power and resistance.

My Life with Charles Billups and Martin Luther King is a reflection of the personal as political not only because of its inherent revisionary approach, but also because Baker was able to write herself into accounts in ways that other accounts rarely included. Baker provides storytelling that directly confronts traditional conventions concerning historical content, personal examples, and critical points of inquiry. Through personal and shared memories, Baker is able to add a significant context and tangibility to her lived experience. She calls attention to the lessons that she learned from her father about forgiveness, but her experiences with trauma required forgiveness to happen on her own terms. Baker calls for a historical weaving that allows for corresponding modes of seeing and knowing in reflections on the civil rights movement. Baker understands literacy histories as inherently intersectional and, therefore, creates an almost seamless, curricular transferability to the fields of Black studies, place studies, history, and education. Baker argues effectively for the necessity of reexamining how research on civil rights, community organizing, and political protests account for our ability to hear the voices of the civil rights movement as well as to listen for the silences. 